\title{
ERŐTANI VIZSGÁLATOK POLIÉTER-ÉTER-ÉTER-KETON (PEEK) ESZTERGÁLÁSA ESETÉN
}

\section{THE INVESTIGATION OF CUTTING FORCES IN TURNING TECHNOLOGY OF PEEK (POLY ETHER ETHER KETONE)}

\author{
Horváth Richárd ${ }^{1}$, Nagy János Zsolt ${ }^{2}$, Hervay Péter ${ }^{3}$ \\ Óbudai Egyetem, Bánki Donát Gépész és Biztonságtechnikai Mérnöki Kar, Anyag- \\ tudományi és Gyártástechnológiai Intézet Cím: 1081, Magyarország, Budapest, \\ Népszínház utca, 8.; Telefon: +36-1-666-5326, \\ horvath.richard@bgk.uni-obuda.hu \\ 2nagy.janos@bgk.uni-obuda.hu \\ 3hervay.peter@bgk.uni-obuda.hu
}

\begin{abstract}
There are more and more engineering plastics in the modern industry, and the area of their application is getting wider. The finish machining of these materials can be done by cutting. There are two important data, which we can use to describe the cutting process of an engineering plastic: forces during cutting and surface roughness. The aim of this paper is to show an experiment, in which we examined the force components during the cutting of a widely used engineering plastic that has favourable properties. We used a full factorial design of experiments, with the aim of predicting cutting force depending on cutting parameters with a predictive model.
\end{abstract}

Keywords: engineering plastic, poly ether ether ketone, PEEK, cutting force, phenomenological model

\section{Összefoglalás}

A müszaki müanyagok folyamatos fejlődése és ipari elöretörése ma már megállíthatatlannak tünik, melyeket egyre szélesebb körben alkalmaznak az iparban. Ezeknek az anyagoknak a befejező megmunkálása történhet forgácsolással. A forgácsolási folyamatot leíró két fontos jellemző a forgácsolásközben fellépő erőhatások, valamint a forgácsolással készített felületi érdesség értéke. Ennek a dolgozatnak a célja egy korszerü, rendkívül kedvező tulajdonságú, széles körben alkalmazható modern müanyag forgácsolása közben fellépő erőkomponensek vizsgálata. A forgácsolási kísérleteknél full faktoriális kísérlettervet alkalmaztunk, melynek célja a forgácsolási paraméterektől függő forgácsolási eredő erő előre történő becslése, prediktív modell felállítása által.

Kulcsszavak: müszaki müanyag, Poli(éter-éter-keton), PEEK, forgácsoló erö, fenomenológiai model

\section{Bevezetés}

A müszaki müanyagok befejező megmunkálása történhet forgácsolással. A mü- szaki müanyagok forgácsolhatósága teljesen eltér a szakirodalomban ismertetett széleskörben felhasznált fémekétől (pl. acélok, alumínium ötvözetek stb.). 
Petropoulos és társai [1] erösítetlen, karbon- és üveg-szállal 30\%-ban erősített kompozitok forgácsolhatóságának vizsgálatát végezte PCD (polikristályos gyémánt) és K15-ös keményfém szerszámmal. A mérés során a forgácsoló sebesség és az előtolás változtatásának a felületi minőségre való hatását vizsgálták és állítottak fel predektív modellt a forgácsolási paraméterek függvényében.

Hanafi és társai [2] tanulmányuk során $30 \%$ karbon-szállal erősített poliéter-éteréter-ketont (PEEK) forgácsoltak titán-nitrid bevonatos szerszámmal. A méréseik során a forgácsoló sebesség, az előtolás és a fogásmélység változásának hatását figyelték meg a forgácsoló erőre.

Mata és társai [3] kísérleteiket erősítetlen, valamint karbon-szállal és üveg-szállal 30\%-ban erősített PEEK forgácsolásával kapcsolatban végezték. Munkájukban empirikus modellt állítottak fel a forgácsoló sebesség és az előtolás hatását figyelembe véve a forgácsoló erőre és a fajlagos forgácsoló eröre.

Hanafi és társai [4] egy másik kutatásukban 30\%-ban karbon-szállal erősített PEEK-el kapcsolatban végeztek forgácsolási kísérleteket. Vizsgálataik során Taguchi optimalizálási módszert alkalmaztak, s keresték a minimálisan alkalmazható forgácsoló erőhöz és a legjobb felületi minőséghez tartozó forgácsolási paramétereket.

Ebben a cikkben a szerzők erősítetlen poliéter-éter-éter-keton (PEEK) forgácsolhatóságának vizsgálatával foglalkoznak. Empirikus modellt állítanak fel a fellépő eredő forgácsolási erőre, mellyel a vizsgált paraméter tartományon belül technológiai előtervezésnek megfelelő pontosággal becsülhetőek az eredő fogácsolási erő értékek.

\section{Anyagok és módszerek}

\subsection{Felhasznált eszközök}

Az esztergálási kísérletekhez egy erősítetlen $\varnothing 60 \mathrm{~mm}$ poliéter-éter-éter-keton (PEEK) rudat használtunk fel.

A forgácsoló kísérletekhez egy egyedileg átalakított és fejlesztett [5] kis erők mérésére alkalmas $(0 \ldots 100 \mathrm{~N})$ SDJCR 2525M-11 kódú szerszámszárt használtunk.

A forgácsoló lapka DCGW 11T304 FN (PCD) volt.

A forgácsolási kísérleteket Dougard Eagle BNC-1800-as eszterga gépen végeztük $\left(\mathrm{P}_{\max }=11 \mathrm{~kW}\right.$, fordulatszám tartománya $\mathrm{n}=100 \ldots 45001 / \mathrm{min}$.), míg az erőmérések kiértékeléséhez a DynoWare programot használtuk.

\subsection{Alkalmazott kísérletterv}

A kísérlettervezés (design of experiment, DOE) során két forgácsolási paramétert $\left(v_{c}-\right.$ forgácsolási sebesség, $\mathrm{m} / \mathrm{min} ; f$ - előtolás, mm) ekvidisztáns (azonos távolságú) módon változtattuk 6 szinten. A fogásvételt $(a, \mathrm{~mm})$ konstans értéken tartottuk ( $a=0,5 \mathrm{~mm})$, melyet az indokolt, hogy a PEEK fogácsolása során legtöbbször simító megmunkálást szoktak alkalmazni. A hat forgácsló sebesség és a hat előtolás értékböl 36 méséri pont adódott. A forgácsolási paraméterek szintjeit az 1. táblázat tartalmazza.

1. táblázat. Forgácsolási paraméterek szintjei

\begin{tabular}{|c|c|c|c|}
\hline \multirow{2}{*}{ 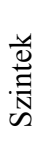 } & \multicolumn{3}{|c|}{ Forgácsolási paraméterek } \\
\hline & $\begin{array}{c}\text { forgácsolási } \\
\text { sebesség, vc, } \\
\text { m/min }\end{array}$ & $\begin{array}{l}\text { elötolás, } \mathrm{f} \text {, } \\
\text { mm }\end{array}$ & $\begin{array}{l}\text { fogás- } \\
\text { mélység, } \\
\text { a,mm }\end{array}$ \\
\hline 1 & 50 & 0,05 & \multirow{6}{*}{0,5} \\
\hline 2 & 120 & 0,12 & \\
\hline 3 & 190 & 0,19 & \\
\hline 4 & 260 & 0,26 & \\
\hline 5 & 330 & 0,33 & \\
\hline 6 & 400 & 0,4 & \\
\hline
\end{tabular}




\subsection{Mért erőkomponensek}

Az 1. ábra mutatja az esztergálás közben fellépő térbeli erőrendszert, valamint az esztergálás mozgásviszonyait. A méréseink során mértük mindhárom erőkomponenst, úgymint: $F c$ - főforgácsoló erő, N; $F f$ előtolás irányú erő, $\mathrm{N} ; F p$ - radiális irányú erő (ún. passzív erő, $\mathrm{N}$ ).

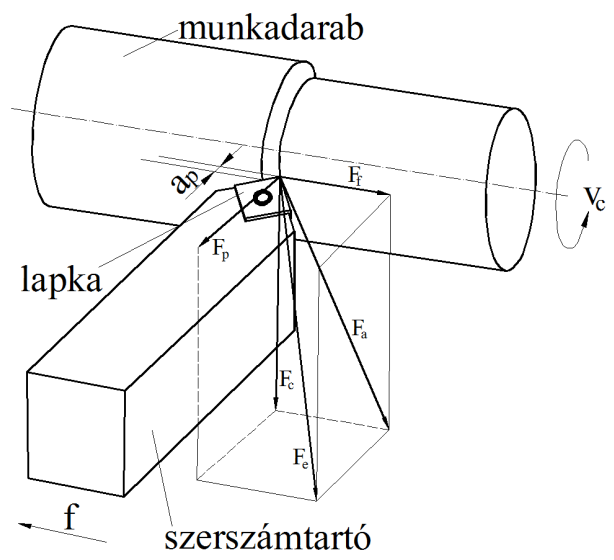

1. ábra. Esztergálás térbeli erörendszere és mozgásviszonyai

A mért értékekből az eredő forgácsoló erőt határoztuk meg az alábbi képlet alapján:

$$
F_{e}=\sqrt{F_{c}^{2}+F_{f}^{2}+F_{p}^{2}}
$$

ahol,

$F C$ - főforgácsoló erő, N;

$F f$ - elötolás irányú erő, $\mathrm{N}$;

$F p$ - radiális irányú erő (ún. passzív erő), $\mathrm{N}$.

\section{Eredmények}

Az Fe (eredő) erők meghatározása után elvégeztük a bemeő paraméterekre a szignifikancia viszgálatokat, és azt találtuk, hogy az $\mathrm{Fe}$ eredő erő paraméterre csak az előtolásnak van lineáris hatása, míg a forgácsoló sebesség hatása elhanyagolható. Ezt jól mutatják a föhatás ábrák is (2. ábra.)

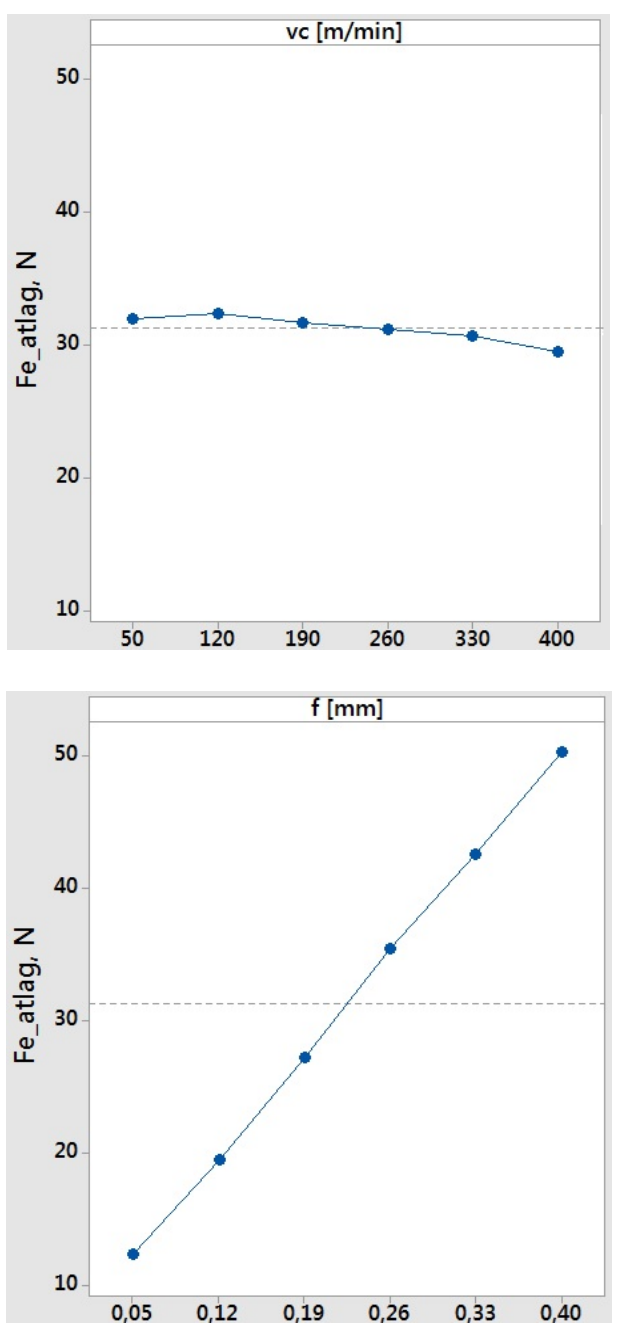

2. ábra. A forgácsolósebesség és az elötolás föhatás ábrái az eredö forgácsoló eröre

A szignifikancia vizsgálatok utána az alábbi egyenletet építettük az $F$ e eredő erő meghatározására:

$$
\begin{aligned}
& \mathrm{F}_{\mathrm{e}}=6,76+ 108,94 \cdot \mathrm{f} \\
&\left(\mathrm{R}^{2}=0,9887\right)
\end{aligned}
$$

ahol

$\mathrm{Fe}$ - eredő forgácsoló erő, N;

$f$ - elötolás, $\mathrm{mm}$. 
A 3. ábra a reziduumvizsgálat eredményeit mutatja. Az ábrán a mért és a becsült értékek különbségét ábrázoltuk normalitás hálón. A 3. ábrából látszik, hogy az általunk épített egyenlet (2) hibái normális eloszlást mutatnak az átlaguk nulla körüli érték, míg a szórás 1,4 N.

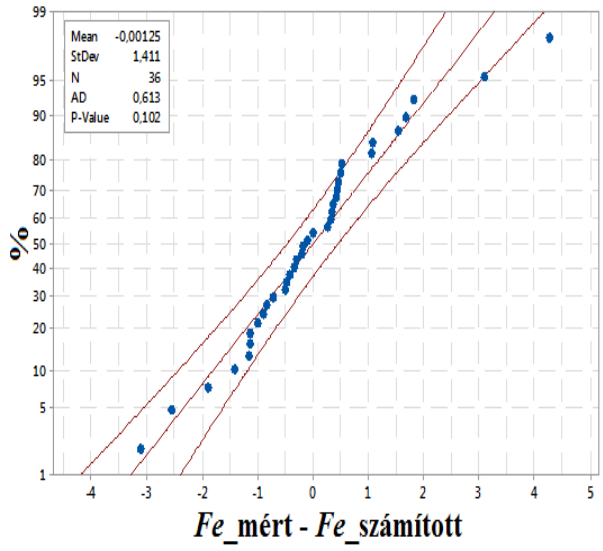

3. ábra. A model hibáinak ábrázolása normalitás hálón

\section{Következtetések}

Ebben a cikkben a szerzők erősítetlen PEEK müszaki müanyag forgácsolhatóságának vizsgálatát végezték el esztergálás körülményei között mesterséges gyémánt szerszámmal. A forgácsolás erőigénye és annak becslése volt az elsődleges szempont. Kutatásunkat kísérletterv segítségével végeztük el 6 forgácsoló sebesség és 6 előtolás kombináció adta a mérési pontokat. Vizsgálatainkból az alábbi következtetéseket lehet levonni:

- az erősítetlen PEEK forgácsolása közben az eredő csak az előtolástól függ, a forgácsoló sebességnek nincs hatása a fellépő eredő eröre;
- empirikus modellt alkottunk mellyel megfelelő pontosságal becsülhető a forgácsolási erő eredő értéke simító esztergálás technológiájánál a vizsgált paramétertartományban;

- a reziduum vizsgálat bebizonyította, hogy a modellből számított és mért értekek közötti eltérés (a modell hibája), normális eloszlást mutat. Várható értéke nulla körüli, míg a szórása igen kicsinek $(1,4 \mathrm{~N})$ mondható.

\section{Köszönetnyilvánítás}

AZ EMBERI ERŐFORRÁSOK MINISZTÉRIUMA ÚNKP-16-4/I. KÓDSZÁMÚ ÚJ NEMZETI KivÁLóSÁG PROGRAMJÁNAK TÁMOGATÁSÁVAL KÉSZÜLT

\section{Szakirodalmi hivatkozások}

[1] Petropoulos, G., F. Mata, and J. Paulo Davim: Statistical study of surface roughness in turning of peek composites. Materials \& Design 29.1, 2008, 218-223.

[2]Hanafi, I., Khamlichi, A., Cabrera, F. M., López, P. J. N., Jabbouri, A.: Fuzzy rule based predictive model for cutting force in turning of reinforced PEEK composite. Measurement, 45(6), 2012, 1424-1435.

[3] Mata, F., Gaitonde, V. N., Karnik, S. R., Davim, J. P.: Influence of cutting conditions on machinability aspects of PEEK, PEEK CF 30 and PEEK GF 30 composites using PCD tools. Journal of materials processing technology, 209(4), 2009, 1980-1987.

[4]Hanafi, I., Khamlichi, A., Cabrera, F. M., Almansa, E., Jabbouri, A.: Optimization of cutting conditions for sustainable machining of PEEK-CF30 using TiN tools. Journal of Cleaner Production, 33, 2012, 1-9.

[5]Horvath, R., Palinkas, T., Matyasi, Gy., Dregelyi-Kiss, Á. The design, calibration and adaption of a dynamometer for fine turning. International Journal of Machining and Machinability of Materials, 19:(1), 2017, 116. 